\title{
Optimising the management of Scots pine (Pinus sylvestris L.) stands in Spain based on individual-tree models
}

\author{
Marc Palahía* and Timo Pukkala ${ }^{b}$ \\ ${ }^{a}$ European Forest Institute, Torikatu 34, 80100 Joensuu, Finland \\ ${ }^{\mathrm{b}}$ University of Joensuu, Faculty of Forestry, PO Box 111, 80101 Joensuu, Finland
}

(Received 31 August 2001; accepted 13 May 2002)

\begin{abstract}
The article describes a simulation-optimisation system, SPINE, for the management of Pinus sylvestris L. stands in Spain. The simulation sub-system is based on an individual-tree diameter growth model, a static individual-tree height model, and models for the selfthinning limit and the probability of a tree to survive for the coming 5-year period. The simulation sub-system was combined with the optimisation algorithm developed by Hooke and Jeeves. The combined simulation-optimisation system is able to find the optimal timing and intensity of thinnings and the optimal time to commence regenerative cuts. The set of regenerative cuts consisted of a preparatory cut, a seed cut 10 years later and a final cut 20 years after the preparatory cut. The decision variables were thinning times, expressed as years since stand establishment or previous thinning, and the remaining stand basal area after each thinning. The system was used to find optimal management schedules of Pinus sylvestris stands on site indices 17, 24 and $30 \mathrm{~m}$ (dominant height at 100 years). When soil expectation value with $2 \%$ discounting rate was maximised, the optimum management schedule included five thinnings on all site indices. The optimal rotations from stand establishment to the final cut were 119, 90 and 94 years, respectively, on site indices 17, 24, $30 \mathrm{~m}$. On all sites, the optimal management schedules were sensitive to the discounting rate, management objective (soil expectation value, forest rent or mean annual harvest) and fixed harvesting costs. Changes of up to 30 percent from the optimal value in a single decision variable did not affect much the soil expectation value.
\end{abstract}

simulation / management schedule / forest management

Résumé - Optimisation de l'aménagement des peuplements de pin sylvestre en Espagne basée sur des modèles simulant la croissance individuelle des arbres. L'article décrit un système de simulation et optimisation, SPINE, pour la sylviculture des peuplements de pin sylvestre en Espagne. Le sous-système de simulation est basé sur un modèle de croissance en diamètre et un modèle statique de centrés-individu, et des modèles pour la limite d'éclaircie naturelle et la probabilité de survie pendant la période des 5 années suivantes. Le sous-système de simulation était combiné avec l'algorithme d'optimisation développé par Hooke et Jeeves. La combinaison des systèmes simulation-optimisation est capable de trouver le rythme et l'intensité optimale des éclaircies ainsi que le temps optimal pour commencer les coupes de régéneration. Les coupes de régéneration consistaient en une coupe préparatoire, une coupe d'ensemencement 10 ans plus tard et une coupe finale 20 ans après la coupe préparatoire. Les variables de décision étaient des périodes d'éclaircies, exprimées comme années après l'etablissement du peuplement ou années après l'éclaircie précédente, et la surface terrière du peuplement résiduel après chaque éclaircie. Le système était utilisé pour trouver des scénarios sylvicoles optimaux pour les peuplements de pin sylvestre pour des indices de fertilité de 17, 24 et $30 \mathrm{~m}$ (hauteur dominante à 100 années). Quand la valeur d'attente du fonds, pour un taux d'escompte de $2 \%$, était maximisée, le scenario de sylviculture comprenait cinq éclaircies sur toutes les stations. Les révolutions optimales, de l'établissement du peuplement jusqu'à la coupe finale, étaient 119, 90 et 94 ans, respectivement pour des indices de fertilités de 17,24 et $30 \mathrm{~m}$. Sur toutes les stations, les scénarios de sylviculture optimaux étaient sensibles au taux d'escompte, coût fixe des coupes et objectifs de gestion (valeur d'attente du fonds, coupe annuelle et moyenne). Des changements jusqu'à $30 \%$ de la valeur optimale d'une variable de décision n'influençait pas beaucoup la valeur d'attente du fonds.

simulation / sylviculture / optimisation / gestion forestière

\section{INTRODUCTION}

Scots pine (Pinus sylvestris L.) forms large forests in most of the mountainous areas of Spain, occupying an area of 1280000 ha [20]. Efficient management of these forests is very important to Spanish forestry because of their economic, ecological and social roles.
Traditionally, decisions on the optimum stand management schedule have been based on expert knowledge and field experiments incorporating sets of treatment regimes. However, these experiments, consisting of a limited selection of treatment alternatives, can only partially assist the solving of the complex problem on the optimum combination of the number, timing and type of thinnings, and the rotation length.

\footnotetext{
${ }^{*}$ Correspondence and reprints

Tel.: +34932687 700; fax: +34932683 768; e-mail: marc.palahi@ctfc.es

Current address: Centre Tecnológic Forestal de Catalunya, Fundació Catalana per la Recerca, Pg. Lluís Companys, 23 , 08010 Barcelona, Spain
} 
Table I. Summary of the characteristics of the three plots used in the study ${ }^{\mathrm{a}}$.

\begin{tabular}{ccccc}
\hline Plot & $H_{\text {dom }}$ & $T$ & $S I$ & $N$ \\
\hline 17 & 5.8 & 24 & 17 & 2228 \\
24 & 10.7 & 25 & 24 & 1934 \\
30 & 12 & 19 & 30 & 2069
\end{tabular}

a $\mathrm{N}$ : the number of trees per hectare; T: stand age; SI: site index at 100 years; $H_{\text {dom }}$ : dominant height.

Determination of the optimum combination of many variables needs a set of models and a simulator able to predict the stand development under any set of management parameters. Seeking for the best set of management parameters can be automated by using optimisation [1, 5, 9, 11, 14, 17, 27, 31].

In this study a stand management support system, SPINE, was developed to support decision-making in the management of Pinus sylvestris stands in Spain. The system consists of a stand growth and yield simulator based on individual-tree growth and mortality models, and an optimisation algorithm, which finds the optimum management schedule for a given objective function. The system was used to optimise the management of $P$. sylvestris stands on three different sites. Sensitivity of the optimal management schedule to the discounting rate, management objective, timber prices and harvesting costs was analysed.

\section{MATERIALS AND METHODS}

\subsection{Simulation model}

\subsubsection{Initial stand}

The simulation model accepts two alternative ways of describing the stand and to initialise the simulation - a list of trees in a plot or a diameter distribution of the stand. In the latter case, which was used in our study, the program requires the stand age $(T)$, site index (dominant height at 100 years), the class mid-point diameters and the number of trees in different diameter (dbh) classes. Every diameter class is represented by the class mid-point tree. After reading the initial stand the program calculates the dominant height $\left(H_{d o m}\right)$ from stand age and site index, using equation (3). Dominant diameter $\left(D_{d o m}\right)$ is calculated from tree diameters, as the average diameter of the $100 \mathrm{ha}^{-1}$ thickest trees. Finally, tree heights are computed from dbh, $D_{d o m}, H_{d o m}$ and $T$ by using equation (4).

In this study, measurements of three inventory plots were used as starting points for stand simulation (table I). The plots were pure even-aged stands of Scots pine. They represented poor, medium and good site fertility, and all had around 2000 trees per hectare indicating that there had been a pre-commercial thinning in each stand (as was assumed in the calculation of soil expectation value). The plots were measured during the Second Spanish National Forest Inventory in 1991 and are located in the province of Girona in the north-east of Spain.

\subsubsection{Simulation of growth}

The simulation of stand development is based on individual tree growth and mortality models. The stand growth simulator uses a dominant height model [22], an individual-tree diameter growth model, a static individual tree height model and survival functions developed by Palahí et al. [23].

The simulation of one 5-year time step consists of the following steps:

1. For each tree, increment tree ages by 5 years and add the 5 -year diameter increment to the diameter, using:

$$
\begin{aligned}
i d 5= & 4.1786-0.0070 \times d b h-8.0476 \times \frac{1}{d b h}+0.6945 \times \frac{d b h}{T} \\
& -0.0042 \times B A L-1.1092 \times \ln (G)+0.0764 \times S I
\end{aligned}
$$

where $i d 5$ is future diameter growth ( $\mathrm{cm}$ per 5 years); $d b h$ is diameter at breast height $(\mathrm{cm}), B A L$ competition index measuring the total basal area of trees larger than the subject tree $\left(\mathrm{m}^{2} \mathrm{ha}^{-1}\right) ; T, G$ and $S I$ are stand age (years), basal area $\left(\mathrm{m}^{2} \mathrm{ha}^{-1}\right)$ and site index $(\mathrm{m})$ at an index age of 100 years, respectively.

2. Multiply the frequency of each tree (number of trees per hectare that a tree represents) by the 5-year survival probability. The survival probability is calculated by equation (2):

$$
P(\text { survive })=\frac{1}{1+\exp \left(-\left(3.954-0.035 \times B A L+2.297 \times \frac{d b h}{T}\right)\right)}
$$

3. Calculate stand dominant height from the site index and incremented stand age using equation (3), and calculate the dominant diameter from incremented tree diameters:

$H_{d o m}=\frac{T^{2}}{\left(18.6269+\left(T \times \frac{100}{S I}-0.03119 \times 100-\frac{18.6269}{100}+0.03119 \times T\right)\right)}$

where $H_{d o m}$ is dominant height at age $T$.

4. Calculate tree heights using equation (4):

$h=1.3+\left(H_{d o m}-1.3\right) \times\left(\frac{d b h}{D_{d o m}}\right)^{\left(0.5546-0.3317 \times\left(\frac{d b h}{D_{d o m}}\right)-0.0015 \times T\right)}$

where $h$ is tree height $(\mathrm{m})$ and $D_{d o m}$ is dominant diameter $(\mathrm{cm})$ of the stand

5. Calculate the self-thinning limit (Eq. (5)). If the limit is exceeded, remove trees until the self-thinning limit is reached, starting with the trees with the lowest survival probability (Eq. (2)).

$$
\log \left(N_{\text {max }}\right)=5.2060-1.8150-\log (D)+0.0212 \times S I
$$

in which $N_{\max }$ is the highest possible number of trees per hectare and $D$ is the mean square diameter $(\mathrm{cm})$. The mean square diameter is calculated from $D=\sqrt{40000 / \pi \times G / N}$. In equation (5), log stands for the 10-base logarithm.

The total tree volumes are computed using the formula developed by Pita Carpenter [24]:

$$
v=-28.34+2.16 \times h+16.59 \times d^{2}+2.794 \times d^{2} \times h
$$

where $v$ is tree volume in $\mathrm{dm}^{3}, h$ is tree height in $\mathrm{m}$ and $d$ is $\mathrm{dbh}$ in $\mathrm{dm}$. This formula is based partly on the same permanent sample plots which were used to develop the tree growth and mortality models used in the stand simulator [23]. 


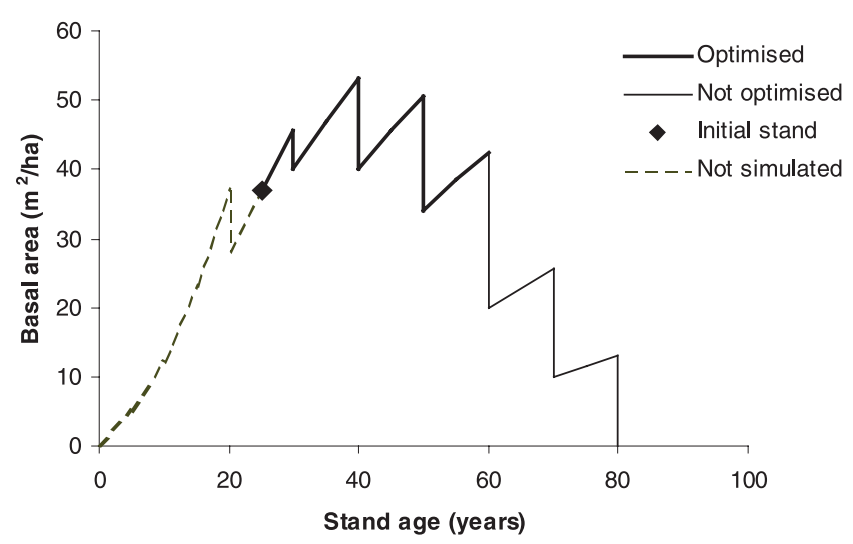

Figure 1. Simulation and optimisation components of a management schedule with one pre-commercial thinning (dashed line), three commercial thinnings (thick solid line) and three regenerative cuts (thin solid line) on site index $24 \mathrm{~m}$ (at 100 years) by using the SPINE system.

\subsubsection{Simulation of thinnings and regenerative cuttings}

The simulation sub-system allows for the simulation of thinnings and regenerative cuttings. Thinning treatments are restricted to thinnings from below since the growth simulation is driven by the dominant height development, which is assumed to be independent of thinnings. When a thinning is simulated, half of the basal area is removed equally from all diameter classes, and the other half as a low thinning, starting with the smallest trees. In this study, the regenerative cuttings were always simulated by mimicking the uniform shelterwood method, which is a very common shelterwood reproduction method used in Spanish Scots pine stands [28]. The purpose of this method is to accomplish the regeneration of the site under the shade and protection of the final crop trees, while providing good soil protection [7]. The shelterwood method as applied in this study included three successive cuts during the 20 last years of the rotation:

- A preparatory cut, which is meant to improve crown development and seedbed conditions. The remaining stand basal area in this study was always $20 \mathrm{~m}^{2} \mathrm{ha}^{-1}$.

- A seed cut was fixed to take place 10 years after the preparatory cut leaving a remaining basal area of $10 \mathrm{~m}^{2} \mathrm{ha}^{-1}$. The purpose of this cut is to open the canopy to favour regeneration.

- A final cut that would remove all remaining parent trees was simulated 10 years after the seed cut.

Figure 1 illustrates the simulation of stand development indicating the optimised and fixed management parameters.

\subsection{Economic data}

\subsubsection{Costs}

Logging costs were based on the unit price tariffs of forestry activities (Cuadro de precios unitarios de la actividad forestal) published by the Asociación y Colegio de Ingenieros de Montes [2] and on a study by Montero et al. [19]. The tabulated tariff values were smoothed to form a model of the total logging cost as a function of tree size (figure 2):

$$
c=\exp [9.407-0.506 \times \ln (d b h)]
$$

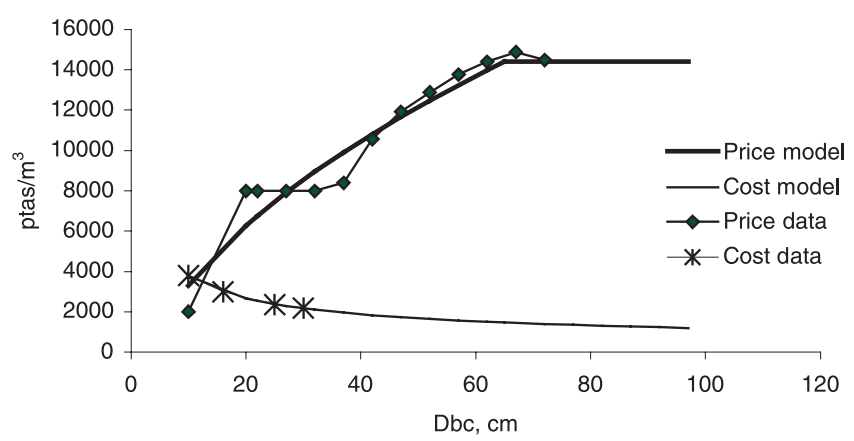

Figure 2. Timber prices and harvesting costs data, and the smoothed price and cost models based on the data points.

where $c$ is logging cost in pesetas (ptas) $\mathrm{m}^{-3}$ and $d b h$ is breast height diameter in $\mathrm{cm}$.

A cost of 1000 ptas $\mathrm{m}^{-3}$ was added to this cost covering the removal of cutting residuals [19]. An entry cost of 600 ptas ha $^{-1}$ was also assumed, consisting of the authorisation of logging plus the cost of marking the trees to $\log$ [19]. In addition to these, the costs of a precommercial thinning were assumed to take place in year $t$ after stand establishment, the tending year depending on site index as follows:

$$
t=35-0.677 \times S I \text {. }
$$

The tending cost was always $100000 \mathrm{ptas} \mathrm{ha}^{-1}$. This cost is based on data provided by the Forest Technology Centre of Catalonia. The tending year function was estimated based on a study by Montero et al. [19] who suggested that the pre-commercial thinning in Scots pine stands should take place between stand age 15 to 25 years depending on stand growth. An annual fire protection cost of 1500 ptas ha $^{-1}$ [19] was also included in the calculation of soil expectation value and mean annual income.

\subsubsection{Incomes}

It was assumed that the road-side timber price is $8000 \mathrm{ptas} \mathrm{m}^{-3}$ for the diameter class of $27.5 \mathrm{~cm}$. This price is based on a study by Díaz Balteiro and Prieto Rodríguez [8] who assumed the price for trees that were not appropriate for veneer logs. The basic price of $8000 \mathrm{ptas} \mathrm{m}^{-3}$ of trees larger than $34 \mathrm{~cm}$ was multiplied by an index based on the study of Montero et al. [18]. The index increased with diameter. The indices have been computed based on the assumption that larger diameters produce a larger percentage of wood for veneer sheets, which have a price four times higher than wood without that characteristic [18]. The price for small diameter classes, mainly coming from thinnings, was estimated from data collected by the Forest Technology Centre of Catalonia during the preparation of the latest forest management plans in 2001. All these tabulated price values were smoothed to give the road-side price as a function of tree diameter (figure 2):

$$
p=-3867+2268 \times \sqrt{D_{p}}
$$

where $p$ is a roadside timber price $\left(\right.$ ptas $\left.^{-3}\right)$ and $D_{p}$ is $\mathrm{dbh}(\mathrm{cm})$ for trees smaller than $65 \mathrm{~cm}$ in diameter, and $65 \mathrm{~cm}$ otherwise (i.e. $65 \mathrm{~cm}$ is used if dbh exceeds $65 \mathrm{~cm}$ ).

\subsection{Objective functions}

The management schedule of each stand was optimised using soil expectation value (SEV) as the objective variable, which is defined as the net present value of all future net incomes [25, 29]. 
The net present value (NPV) of all the management operations in a rotation, discounted to the beginning of the rotation, is:

$$
N P V=\sum_{t=1}^{R} \frac{N_{t}}{(1+i)^{t}}
$$

where $N$ is the net income from a management operation, $i$ is the discounting rate, $t$ is the year of the operation and $R$ is the rotation age. The NPV of an infinite series of future harvests is referred to as the soil expectation value (SEV) and can be computed from:

$$
S E V=\frac{N P V}{1-\frac{1}{(1+i)^{R}} .}
$$

The SEV is a justified management objective if a single economic goal must be selected [17]. The discounting rate used was $2 \%$. Díaz Balteiro and Prieto Rodríguez [8] proposed this discounting rate based on the fact that $2 \%$ is very close to the rate of return of the public debt in Spain. Other studies [13] also support the suitability of this discounting rate value. A sensitivity analysis was conducted using discounting rates of $1 \%$ and $3 \%$ to study the effect of this parameter on the optimal management schedule.

In addition to the SEV, the mean annual net income, i.e. forest rent (FR), and the mean annual harvested volume (WP) were used as objective functions to study the sensitivity of the optimal management to the type of objective variable.

\subsection{Decision variables}

Optimising the management schedule means finding the optimal values for a set of decision variables (DV). Because the number of thinnings is not a continuous variable, schedules with different number of thinnings are to be treated as separate optimisation problems. The management regime was specified by the number of thinnings, and by the DVs, which were chosen as follows:

For each thinning:

- Years since previous thinning, or if it is the first thinning stand age when the thinning occurs.

- Remaining basal area.

For final cuttings:

- Years since the last thinning to the first regenerative cut.

The number of decision variables $(N D V)$ depends on the number of thinnings $(N T H)$ as follows:

$$
N D V=2 \times N T H+1 .
$$

\subsection{Optimisation method}

The simulation model described above was linked to the direct search method of Hooke and Jeeves [12] that was used as the optimisation algorithm. This algorithm has been commonly used for optimising the management of both even-aged stands [14, 16, 21, 26, $27,30]$ and uneven-aged stands $[3,11,21]$. The direct search method algorithm operates using two search modes: exploratory search and pattern search. Given a base point (a vector of DVs), the exploratory search examines points around the base point in the direction of the coordinate axes (DVs). The pattern search moves the base point in the direction defined by the previous base point and the best point of exploratory search (for more details see [4]).

The combined simulation-optimisation system is capable of finding the optimal treatment schedule for a given stand, when the number of thinnings, the economic parameters (timber prices, harvesting costs, discounting rate, etc.) and the objective variable are specified. An estimate of the optimal combination of DVs is used as



Figure 3. Development of stand volume in the optimal management schedule for maximum soil expectation value on site indices 17,24 and $30 \mathrm{~m}$ (at 100 years).

the initial solution for the optimisation program. The program calls the simulation sub-system which reads the economic parameters and the initial stand characteristics and computes the value of the selected objective variable (objective function). Based on the feed back from the simulation sub-system, the optimisation sub-system alters the values of the DVs by using the exploratory and pattern search of the optimisation algorithm. The simulation sub-system re-calculates the objective function with the new DVs values. The optimal management schedule for a given number of thinnings is eventually found, after repeating this search-process as many times as defined by a convergence criterion. The optimisation was carried out for $0,1,2$, 3,4 , and 5 thinnings to find the number of thinnings that maximised the objective variable.

Because the optimisation algorithm does not necessarily converge to the global optimum, all optimisations were repeated 51 times, each run starting from the best of 200 random combinations of DVs, except the first one, which started from a user-defined starting point. The random values of DVs were uniformly distributed over a userspecified range. The following ranges were used:

- year of the first thinning: 5-80;

- intervals of later cuttings: 5-40 years;

- remaining basal area in a thinning: $5-40 \mathrm{~m}^{2} \mathrm{ha}^{-1}$.

These ranges only concerned the random searches in the beginning of each direct search; the direct search was allowed to go outside these ranges. The initial step-size in altering the values of DVs in the direct search was 0.1 times the range. The step size was gradually reduced during the direct search, and the search stopped when the step size of all DVs was less than 0.00005 times the initial range (convergence criterion).

\section{RESULTS}

\subsection{Optimal management schedule}

On all site indices $(17,24$ and $30 \mathrm{~m}$ ) five thinnings were needed to maximise the objective function (figure 3 ). On site index 17 the first thinning took place immediately (24 years) and there was no preparatory cut because the last thinning (at 94 years) left a remaining basal area smaller than $20 \mathrm{~m}^{2} \mathrm{ha}^{-1}$. 


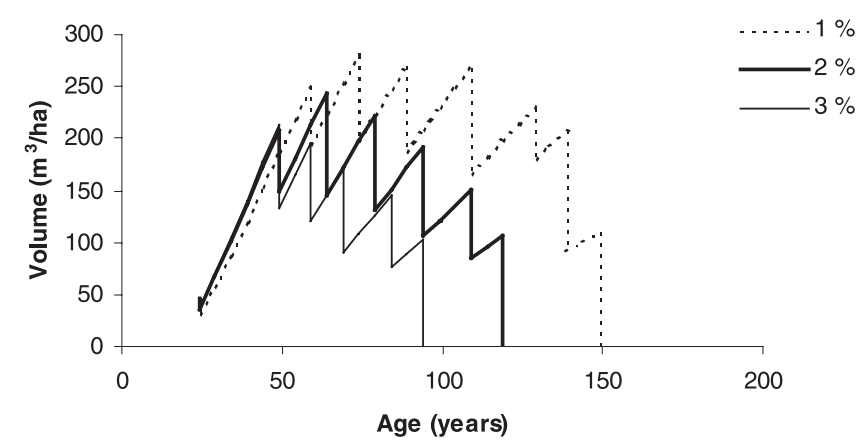

Figure 4. Optimal management schedule on site index $17 \mathrm{~m}$ (at age 100 years) maximising soil expectation value with 1,2 and 3 percent discounting rate.

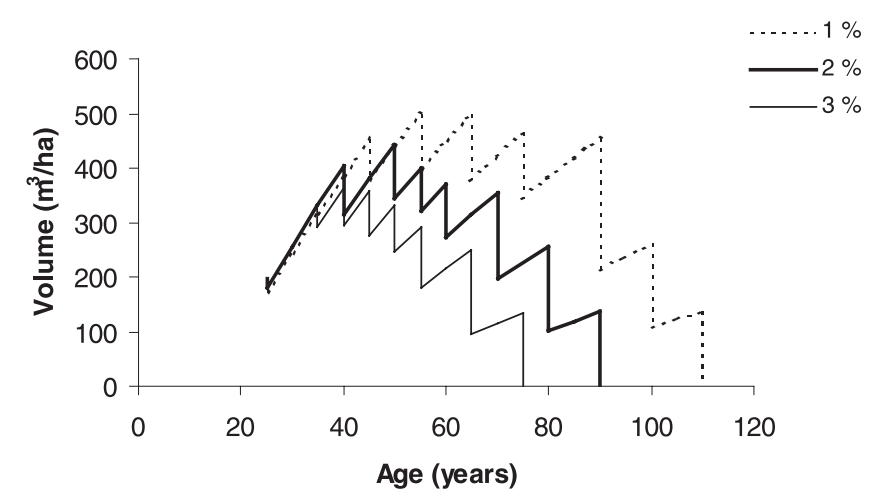

Figure 5. Optimal management schedule on site index $24 \mathrm{~m}$ (at age 100 years) maximising soil expectation value with 1,2 and 3 percent discounting rate.

On site index 24, the first thinning took place immediately and the first regenerative cut (preparatory cut) at a stand age of 70 years, giving an optimal rotation of 90 years with the 20-year shelterwood period. On site index 30 the first thinning occurred at stand age of 44 years and the preparatory cut at 74 years (rotation age 94 years). The SEV of site indices 17, 24 and 30 was 427812, 1500090 and 2269111 ptas ha $^{-1}$, respectively. The mean annual harvest of the optimal regime was $4.3,9.1$ and $14.7 \mathrm{~m}^{-3} \mathrm{ha}^{-1}$ year ${ }^{-1}$, respectively, for site indices 17,24 and $30 \mathrm{~m}$.

\subsection{Sensitivity analysis}

The effect of discounting rate on the optimal schedule is very clear on all sites (figures 4-6). The higher the discounting rate, the sooner the final cuttings start (preparatory cut) and therefore the optimal rotation is shorter. The thinnings become heavier with increasing discounting rate. This result is logical, since it is more profitable to decrease the value of the growing stock, through thinnings and regenerative cuttings, if the return from alternative investments improves.

The stand volume development for maximising SEV, volume production, i.e., mean annual harvest (WP), as well as

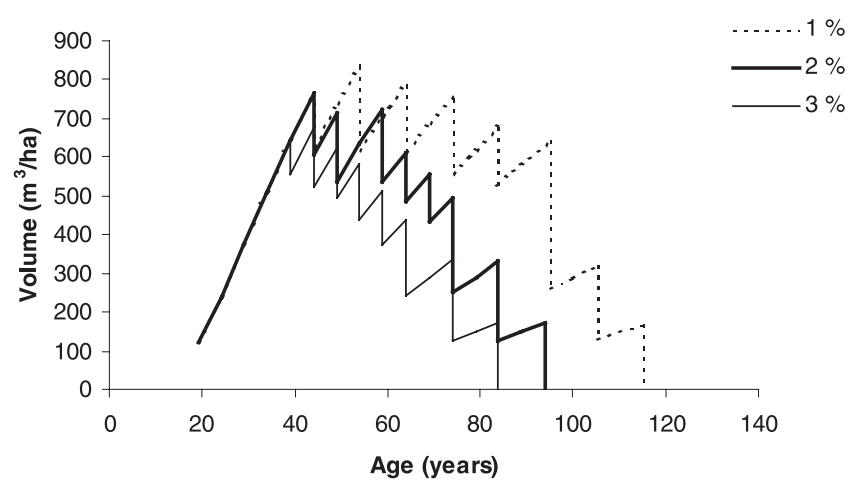

Figure 6. Optimal management schedule on site index $30 \mathrm{~m}$ (at age 100 years) maximising soil expectation value with 1,2 and 3 percent discounting rate.

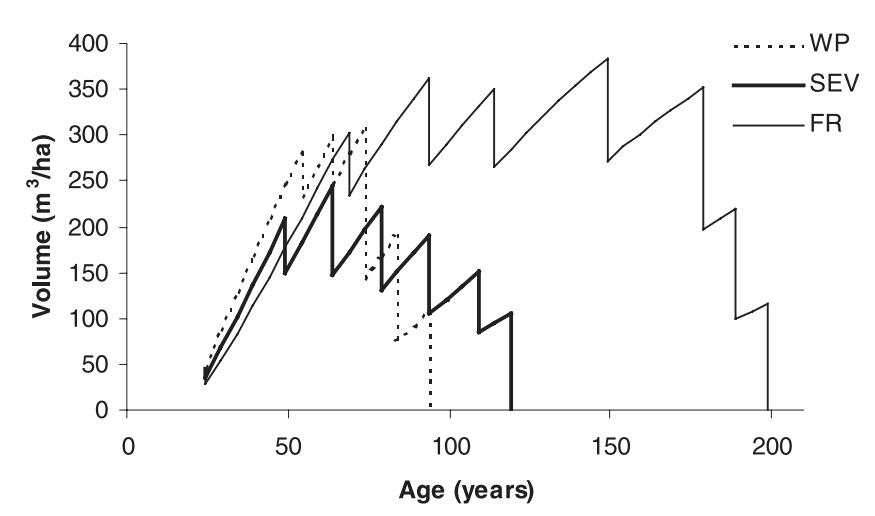

Figure 7. Sensitivity of the optimal management schedule on site index 17 (at age 100 years) to changes in the objective function: maximum mean annual harvest (WP), maximum soil expectation value (SEV) and maximum forest rent (FR).

forest rent (FR) were compared to investigate the sensitivity of the management schedule to the objective function (figures 7-9). The results indicate that if WP is maximised the number of thinnings is reduced to 2 for site index 17 and 1 for site index 24 , while no thinnings are needed on site index $30 \mathrm{~m}$. The mean annual harvest when maximising WP was 5.2, 9.8 and $15.3 \mathrm{~m}^{-3} \mathrm{ha}^{-1}$ year $^{-1}$ for site indices 17,24 and $30 \mathrm{~m}$, respectively. The results (figures 7-9) indicate that the better the site index of the stand the fewer or even no thinnings are needed to maximise WP.

When FR is maximised the rotations in all site indices are much longer than maximising SEV or WP. This is due to the fact that FR, i.e., the mean annual net income, is equivalent to NPV with $0 \%$ discounting rate. Therefore, when maximising this objective function there are no investment alternatives, and since the price of wood increases with timber diameter (until $65 \mathrm{~cm}$ of diameter) and harvesting costs per $\mathrm{m}^{3}$ decrease, rotations are prolonged as long as diameter growth continues to be reasonable. For site indices 24 and $30 \mathrm{~m}$ the optimal rotations for maximising FR are 141 years. For site index 17 the optimal rotation for maximising FR is 199 years. 
Table II. Soil expectation value (SEV, $1000 \mathrm{ptas} \mathrm{ha}^{-1}$ ), forest rent (FR, $1000 \mathrm{ptas} \mathrm{ha}^{-1} \mathrm{year}^{-1}$ ), and mean annual harvest (WP, $\mathrm{m}^{3} \mathrm{ha}^{-1} \mathrm{year}^{-1}$ ) in the optimal schedule when maximising the variable in the first column.

\begin{tabular}{cccccccccc}
\hline $\begin{array}{c}\text { Objective } \\
\text { variable }\end{array}$ & SEV & Site 17 & SR & WP & SEV & FR & WP & \multicolumn{3}{c}{ SEV } & FR & WP \\
\hline SEV & 428 & 24.5 & 4.3 & 1500 & 58.3 & 9.1 & 2269 & 87.9 & 14.7 \\
FR & 245 & 32.0 & 3.8 & 1134 & 68.1 & 8.1 & 1811 & 101.1 & 12.4 \\
WP & 328 & 19.0 & 5.2 & 1399 & 53.8 & 9.8 & 2089 & 75.9 & 15.3 \\
\hline
\end{tabular}

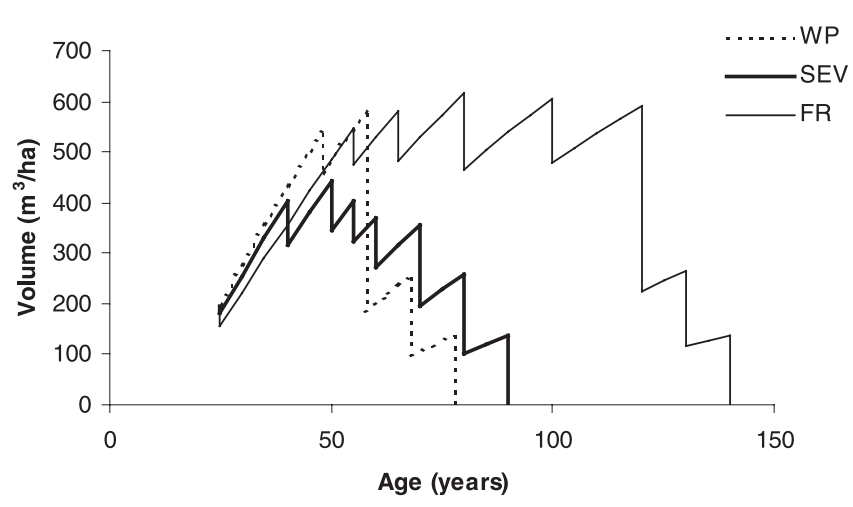

Figure 8. Sensitivity of the optimal management schedule on site index 24 (at 100 years) to changes in the objective function: maximum mean annual harvest (WP), maximum soil expectation value (SEV) and maximum forest rent (FR).



Figure 9. Sensitivity of the optimal management schedule on site index 30 (at 100 years) to changes in the objective function: maximum mean annual harvest (WP), maximum soil expectation value (SEV) and maximum forest rent (FR).

The sensitivity of SEV, FR and WP to the objective variable that is maximised is shown in table II. SEV was the most sensitive to the choice of objective variable, while WP and FR were less sensitive. The results indicate that, on all site indices, SEV decreases more when the objective variable is FR than when it is WP. The mean annual harvest was closer to the maximum WP when maximising SEV than when FR was maximised. Furthermore, the relative sensitivity of SEV, FR and WP to a change in the objective variable is greater on site index 17 than on the other two sites.

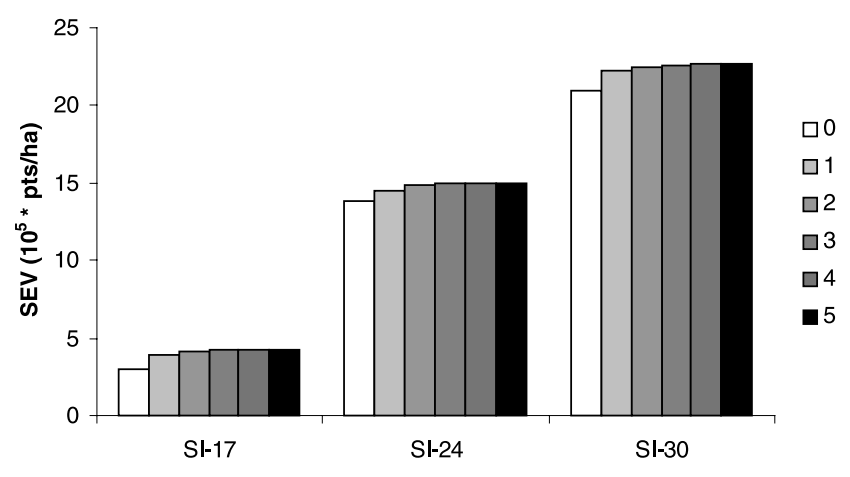

Figure 10. Sensitivity of the maximal SEV to the number of thinnings on site indices 17, 24 and $30 \mathrm{~m}$ (at age 100 years).

The sensitivity of the objective function value (SEV) to changes in the values of the DVs was tested on site index 24 by increasing or decreasing the value of one DV at a time by $10 \%, 20 \%$ and $30 \%$ and re-simulating the management schedule. The SEV was not sensitive to small changes in the DVs (table III). The SEV was the most sensitive to changes in the DVs of the first thinning. The later the change in the DVs took place, the smaller was the change in SEV. From the two DVs that characterised each thinning (years since previous thinning and remaining basal area after thinning) the latter one appeared to have more influence on SEV.

The optimisations of thinnings and rotation length for each number of thinnings constitute different problems with corresponding numbers of variables. The number of thinnings is therefore a parameter given to the simulation-optimisation system at the outset. The maximum SEV for 0, 1, 2, 3, 4 and 5 thinnings on site indices 17, 24 and 30 are shown in figure 10. Although soil expectation value increased with the number of thinnings until the optimum was reached, most of the gain was achieved with just one thinning. Three and four thinnings were practically equally good as the optimal number (i.e., 5 thinnings).

Timber prices and variable harvesting costs were another set of uncertain parameters. We analysed the sensitivity of stand management to prices and costs changes by increasing or decreasing the values of each of these parameters at a time by $15 \%$ and $30 \%$ and re-computing the optimal solution. The results indicate that the optimal management schedule with the SEV as the objective was not very sensitive to the level of timber prices (figure 11) and variable harvesting costs (figure 12). The rotation length was prolonged 10 years when the prices decreased $30 \%$ and 5 years when harvesting costs were increased $30 \%$. The optimal rotation was 10 years 
Table III. Sensitivity of soil expectation value (1000 $\left.\mathrm{ptas} \mathrm{ha}^{-1}\right)$ on site index 24 to changes in decision variables (DVs). The optimal values of DVs for each thinning and the first final cut, i.e., number of years since previous thinning (Y), remaining basal area after thinning (Gr) and years since last thinning to the first final cut (Yc), were independently increased and decreased by 10,20 and 30 percent. After these changes the SEV was calculated again.

\begin{tabular}{|c|c|c|c|c|c|c|c|}
\hline & $-30 \%$ & $-20 \%$ & $-10 \%$ & Optimum & $+10 \%$ & $+20 \%$ & $+30 \%$ \\
\hline \multicolumn{8}{|c|}{ First thinning } \\
\hline $\mathrm{Y}$ & $-*$ & - & 1499.9 & 1500.0 & 1486.7 & 1477.4 & 1463.4 \\
\hline $\mathrm{Gr}$ & 1460.2 & 1482.9 & 1496.0 & 1500.0 & 1483.2 & 1474.4 & - \\
\hline \multicolumn{8}{|c|}{ Second thinning } \\
\hline $\mathrm{Y}$ & 1496.9 & 1497.0 & 1498.1 & 1500.0 & 1497.1 & 1494.7 & 1492.6 \\
\hline $\mathrm{Gr}$ & 1481.6 & 1492.4 & 1498.1 & 1500.0 & 1498.0 & 1492.9 & 1485.9 \\
\hline \multicolumn{8}{|c|}{ Third thinning } \\
\hline $\mathrm{Y}$ & 1498.2 & 1498.7 & 1499.3 & 1500.0 & 1497.9 & 1495.9 & 1493.9 \\
\hline $\mathrm{Gr}$ & 1491.7 & 1496.6 & 1499.2 & 1500.0 & 1498.8 & 1496.2 & 1492.7 \\
\hline \multicolumn{8}{|c|}{ Fourth thinning } \\
\hline $\mathrm{Y}$ & 1498.9 & 1499.1 & 1499.5 & 1500.0 & 1499.3 & 1498.7 & 1498.1 \\
\hline $\mathrm{Gr}$ & 1493.1 & 1497.0 & 1499.3 & 1500.0 & 1499.3 & 1497.5 & 1496.3 \\
\hline \multicolumn{8}{|c|}{ Fifth Thinning } \\
\hline $\mathrm{Y}$ & 1498.9 & 1499.2 & 1499.6 & 1500.0 & 1499.4 & 1498.9 & 1498.3 \\
\hline $\mathrm{Gr}$ & 1491.1 & 1496.0 & 1498.9 & 1500.0 & 1499.2 & 1497.0 & 1493.2 \\
\hline \multicolumn{8}{|c|}{ Preparatory cut } \\
\hline Yc & 1499.5 & 1499.6 & 1499.8 & 1500.0 & 1498.7 & 1497.4 & 1496.1 \\
\hline
\end{tabular}

* Dashes correspond to situations that could not be simulated because the value of the DV was out of the range of the possible development of the stand.

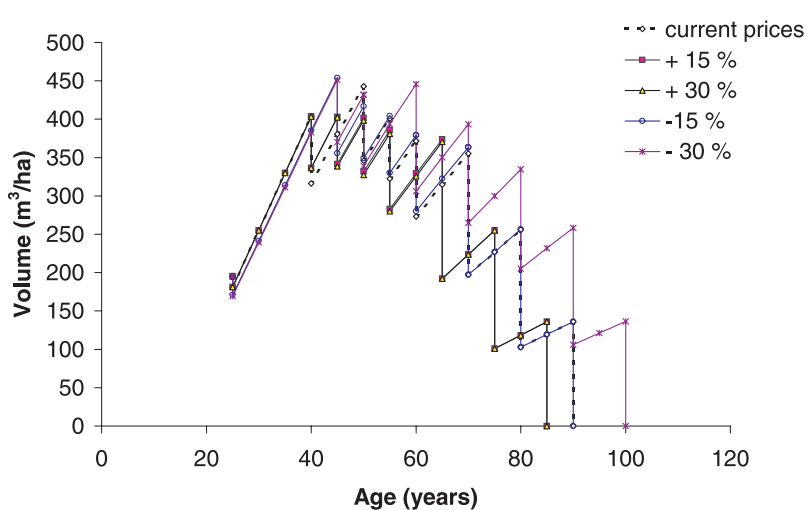

Figure 11. Sensitivity of the optimal management schedule to increasing and decreasing timber prices.

shorter when harvesting costs decreased by $30 \%$. In general, thinnings began later when timber prices decreased or harvesting costs increased.

The fixed entry cost of thinning was based on the administrative and marking costs presented by Montero et al. [19]. These costs are rather low. The sensitivity of optimal management to increased entry costs was analysed in the plot with site index $24 \mathrm{~m}$ (figure 13). Figure 13 shows that increasing entry costs reduce the number of thinnings and the thinnings became heavier. The entry costs do not affect much the length of the optimal rotation.

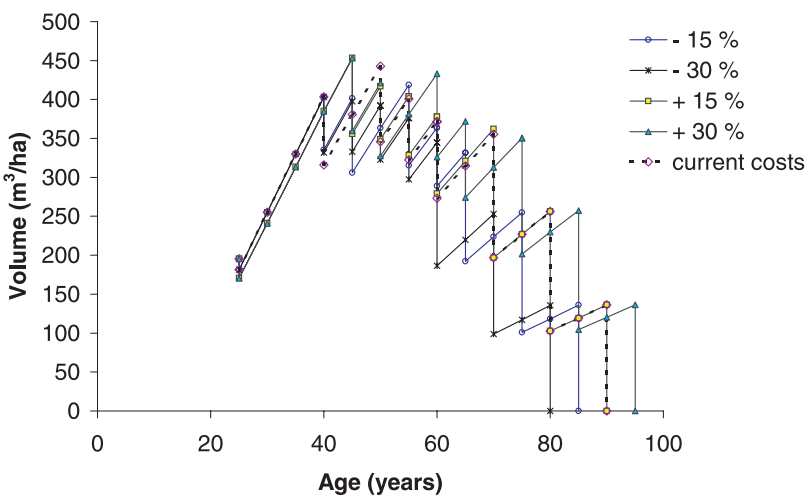

Figure 12. Sensitivity of the optimal management schedule to increasing and decreasing harvesting costs.

\section{DISCUSSION}

The results of this study are based on the models of Palahí et al. [22, 23]. The optimisations for site index 17, when maximising FR, are not as reliable as the other results because a long extrapolation beyond the maximum stand age of the modelling data [23] was required (rotation of 199 years). The results for the plot with site index $30 \mathrm{~m}$ may also be less reliable than the results for the other sites due to an extrapolation beyond the maximum site index of the modelling data. However, although the maximal stand 


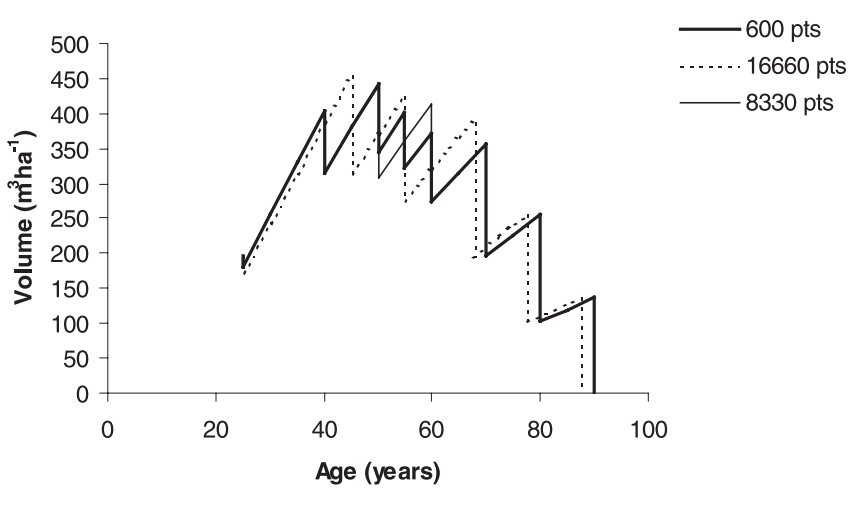

Figure 13. Sensitivity of the optimal management schedule to increasing fixed entry costs on site index $24 \mathrm{~m}$ with $2 \%$ discounting rate.

volumes that the simulator produced for site index $30 \mathrm{~m}$ are very high (figure 9) they are in accordance with the yield tables presented by Rojo and Montero (1996) and used in Montero et al. (1996) for site index $30 \mathrm{~m}$. The set of models used in the simulation program were based on permanent sample plots that ranged from 33 to 148 years in age and from 14 to $26 \mathrm{~m}$ in site index [22, 23]. In stands younger than 148 years the models have been found to follow accurately the measured stand development of permanent sample plots [23].

The reliability of the optimisation algorithm was tested by repeating the optimisation for site index 24 with 3 thinnings for 100 times, each time starting from a different random solution, and analysing the variation among solutions. The standard deviation of soil expectation value was 7223 ptas ha $^{-1}$, which is $0.49 \%$ of the mean. The standard error of mean was only $0.049 \%$. The standard error of rotation length was 0.055 years, which is $0.085 \%$ of the mean. In fact the optimal rotation was practically the same (differences were smaller than 0.05 years) in 98 out of 100 solutions, and 4 years shorter in 2 solutions. The timing of thinnings varied more but the changes were always mutual so that if the interval between two thinnings decreased by, for example, 5 years compared to the previous solution, the next interval increased by 5 years. The length of these swaps was typically about 5 years. The remaining basal area was always practically the same for a given thinning year. The results indicate that the optimisation method was able to find the maximal SEV and optimal rotation with high precision but the optimal timing of thinnings is less precise (it is found with 5-year accuracy). The reason for this uncertainty is that several combinations of cutting intervals are almost equally good, i.e. they produce almost exactly the same SEV.

Although the optimal management of Scots pine stands was not very sensitive to changes in the level of prices, the use of the non-smoothed prices instead of the price model (see figure 2) produced a completely different optimal management schedule. Figure 14 shows that using the non-smoothed prices, a very heavy thinning takes place immediately when the minimum diameter reaches $20 \mathrm{~cm}$. When non-smoothed prices are used, logging of $20 \mathrm{~cm}$ trees produces a distinctly greater net income than logging of trees slightly smaller than $20 \mathrm{~cm}$ (see figure 2).



Figure 14. Stand basal area in the optimal management schedule for site index 24 with $2 \%$ discounting rate and 3 thinnings when using smoothed and non-smoothed timber prices, and the mean diameter development when the non-smoothed price function is used in optimisation.

In addition, increasing tree diameters up to $40 \mathrm{~cm}$ improves the unit price only very little. This comparison shows that it is advisable to carefully check that the information concerning timber prices and harvesting costs are valid for each particular situation in which optimisations are done. The results concerning the sensitivity of the optimal management schedule to changes in the fixed entry costs is in accordance with the study by Filius and Dull [9], which shows that the number of thinnings decreases with increasing fixed entry costs, but rotation length is not much affected.

We are aware of the problems related to the simulation of the same shelterwood cuttings in all optimisations. Previous studies in Spain [28] indicate that it is difficult to specify a single treatment schedule of the uniform shelterwood method for all Scots pine stands in Spain because the system depends on the characteristics of each stand. In this study, the simulated reproductive method is based on a traditionally accepted 20-year period for regenerating Scots pine stands in Spain [19] and on previous studies in Spain [15] that concluded that an average basal area of 12 to $15 \mathrm{~m}^{2} \mathrm{ha}^{-1}$ is adequate to obtain good regeneration in stands of Scots pine. Although technically possible, it was not reasonable to optimise the intervals and post-cutting basal area of the regenerative cuts because the exact relationship between cutting parameters and regeneration result was unknown. Further studies on the density and population structure of natural regeneration such as the one presented by González-Martínez and Bravo [10] are needed to treat the regenerative cuttings as decision variables in the optimisation process.

The analysis conducted in this study indicates that the optimal management schedule of Scots pine stands on site indices 17, 24 and $30 \mathrm{~m}$ are sensitive to the management goal. Maximising WP produces management schedules with fewer thinnings than maximising SEV or FR. The results also show that the better the site index of the stand the fewer thinnings are needed to maximise WP. On site indices 17, 24 and $30 \mathrm{~m}$, 2, 1 and 0 thinnings were needed to maximise WP. Maximising FR calls for much longer rotations than maximising SEV or WP. The results shown in figure 3 , which suggests longer rotations 
for site index $30 \mathrm{~m}$ than for site index $24 \mathrm{~m}$, can be explained by the different initial stand characteristics (diameter distributions) of the two plots.

The results of our optimisations agree fairly well with the previous recommendations by Montero et al. [18, 19], which suggest maximising forest rent and having rotations of 100 to 140 years depending on the site index and the thinning regime. However, in this study SEV was considered to be the most reasonable economic management goal [17]. With the SEV goal, the optimal management schedule was sensitive to the discounting rate, the rotation being shorter and the thinnings earlier and heavier for higher discounting rates. The insensitivity of SEV to changes in any single decision variable indicates that the objective function is a flat function of DVs near the optimum.

The applicability of the system presented depends on the production objectives of the forest. Clutter et al. [6] divided all timber management planning situations into two distinct categories: (1) those situations in which planning can be done independently for each stand; and (2) those situations in which the planning must be co-ordinated for all stands in the forest being considered. The first situation, referred to as stand-level management planning, assumes that each stand is treated in the way that will best meet the goal of the forest owner. In this situation, the stand management support system described in this study can be used directly. Also, the system could be used to produce management instructions for different sites and stand densities. In addition, stand-level optimisations serve comparative analyses on the effects of economic or biological factors on stand management [31].

However, the majority of forests cannot be managed relying only on the stand-level approach because this often produces large fluctuations in annual harvests and revenues. Thus, in situations where stable patterns of income are important, the optimum treatment of a stand will depend on the rest of the forest property, calling for forest-level management planning, corresponding to the second category of Clutter et al. [6]. In this situation, the simulation sub-system may be used to produce relevant information about alternative treatment schedules of stands. This information is then collected into a forest level optimisation model, which is solved using linear programming or other procedures. Standlevel optimisation may be used to guide the simulation of stand management alternatives in forest level planning.

Acknowledgements: Financial support for this project was given by the Forest Technology Centre of Catalonia (Solsona, Spain). We thank Dr. Gregorio Montero (Spain) for his helpful suggestions. We thank Mr. Tim Green for the linguistic revision of the manuscript and Mr. Jo Van Brusselen for the French translation of the abstract.

\section{REFERENCES}

[1] Arthaud G.J., Pelkki M.H., A comparison of dynamic programming and A* in optimal forest stand management, For. Sci. 42 (1996) 498-503.

[2] Asociación y colegio de Ingenieros de Montes, Cuadro de precios unitarios de la actividad forestal, Madrid, 2000, $260 \mathrm{p}$.
[3] Bare B.B., Opalach D., Optimizing species composition in unevenaged forest stands, For. Sci. 33 (1987) 958-970.

[4] Bazaraa M.S., Shetty C.M., Nonlinear programming: Theory and algorithms, Wiley, New York, 1979, $560 \mathrm{p}$.

[5] Brodie J.D., Adams D.M., Kao C., Analysis of economic impacts on thinning and rotation for Douglas-fir, using dynamic programming, For. Sci. 24 (1978) 512-522.

[6] Clutter J.L., Forston J.C., Piennar L.V., Brister G.H., Bailey R.L., Timber management - a quantitative approach, Wiley, New York, 1983.

[7] Daniel T., Helms J., Baker F., Principles of silviculture, 2nd edn., McGraw-Hill, USA, 1979, pp. 446-447.

[8] Díaz Balteiro L., Prieto Rodríguez A., Modelos de planificación forestal basados en la programación lineal. Aplicación al monte "Pinar de Navafria" (Segovia), Invest. Agr.: Recur. For. 8 (1999) $63-92$.

[9] Fillius A.M., Dull M.T., Dependence of rotation and thinning regime on economic factors and silvicultural constraints: results of an application of dynamic programming, For. Ecol. Manage. 48 (1992) 345-356.

[10] González-Martínez S.C., Bravo F., Density and population structure of the natural regeneration of Scots pine (Pinus sylvetrsis L.) in the High Ebro Basin (Northern Spain), Ann. For. Sci. 58 (2001) 277-288.

[11] Haight R.G., Monserud R.A., Optimizing any-aged management of mixed-species stands: II. Effects of decision criteria, For. Sci. 36 (1990) 125-144.

[12] Hooke R., Jeeves T.A., "Direct search" solution of numerical and statistical problems, J. Assoc. Comput. Mach. 8 (1961) 212-229.

[13] Kula E., The economics of forestry: Modern theory and practice, Croom and Helm, London, 1988, 185 p.

[14] Mabvurira D., Pukkala T., Optimising the management of Eucalyptus grandis (Hill) Maiden plantations in Zimbabwe, For. Ecol. Manage. 166 (2002) 149-157.

[15] Martínez de Pisón M., Defensa del método denominado "ordenar transformando". Escuela de Ingenieros de Montes, Madrid, 1948, $108 \mathrm{p}$.

[16] Miina J., Optimizing thinning and rotation in a stand of Pinus sylvestris on a drained peatland site, Scan. J. For. Res. 11 (1996) 182-192.

[17] Miina J., Preparation of stand management models using simulation and optimisation, in: Pukkala T., Eerikäinen K. (Eds.), Tree seedling production and management of plantation forests, University of Joensuu, faculty of Forestry, research notes 68, 1998, pp. 153-163.

[18] Montero G., Rojo A., Alia R., Determinación del turno de Pinus sylvestris en el Sitema Central, Montes, 29 (1992) 42-48.

[19] Montero G., Rojo A., Del Rio M., Aspectos selvícolas y económicos de los pinares de Pinus sylvestris L. en el Sistema Central, proceedings of the open seminar: "Explotación y conservación del monte mediterráneo: una apuesta para el futuro", Unversidad de Málaga, Ronda, Málaga, 1996.

[20] Montero G., Cañellas I., Ortega C., Del Rio M., Results from a thinning experiment in a Scots pine (Pinus sylvestris L.) natural regeneration stand in the Sistema Ibérico Mountain Range (Spain), For. Ecol. Manage. 145 (2001) 151-161.

[21] Muchiri M., Pukkala T., Miina J., Optimising the management of maize Grevillea robusta fields in Kenya, Agroforestry systems 56 (2002) 13-25.

[22] Palahí M., Tomé M., Pukkala T., Trasobares A., Montero G., Site index model for Scots pine (Pinus sylvestris $\mathrm{L}$.) in north-east Spain, For. Ecol. Manage. (submitted).

[23] Palahí M., Pukkala T., Miina J., Montero G., Individual-tree growth and mortality models for Scots pine (Pinus sylvestris L.) in northeast Spain, Ann. For. Sci. 60 (2002) 1-10.

[24] Pita Carpenter A., Tablas de cubicación por diámetros normales y alturas totales, Instituto Forestal de Investigaciones y Experiencias, Ministerio de Agricultura, Madrid, 1967.

[25] Price C., The theory and application of forest economics, Basil Blackwell, Oxford, 1989, 402 p. 
[26] Rautiainen O., Pukkala T., Miina J., Optimising the mangement of even-aged Shorea robusta stands in southern Nepal using individual tree growth models, For. Ecol. Manage. 126 (1999) 417-429.

[27] Roise J.P., An approach for optimizing residual diameter class distributions when thinning even-aged stands, For. Sci. 32 (1986) 871-881.

[28] Rojo A., Montero G., El pino silvestre en la Sierra de Guadarrama, Centro de publicaciones del Ministerio de Agricultura, Pesca y Alimentación, 1996, 293 p.
[29] Rose D.W., Brand G.J., Guide to forest investment analysis. USDA Forest Service Research Paper NC-284, North Central Forest Experiment Station, St. Paul, MN, 23 p.

[30] Valsta L., A comparison of numerical methods for optimizing even aged stand management, Can. J. For. Res. 20 (1990) 961-969.

[31] Valsta L., An optimization model for Norway spruce management based on individual-tree growth models, Acta Forestalia Fennica 232 (1992) $20 \mathrm{p}$. 